\title{
Family Climate and Peer Pressure as Correlate of Students' Academic Achievement in Social Studies in Ebonyi State, Nigeria
}

\author{
Dr. Athanatius Ifeanyi IBEH \\ Department of Education Social Studies \\ Ebonyi State College of Education \\ Ikwo, Ebonyi State \\ Nigeria \\ Enekwe, Chukwudi Bendict \\ Department of Integrated Science \\ Ebonyi State College of Education \\ Ebonyi State
}

\begin{abstract}
The study investigated family climate and peer pressure as correlates of students' academic achievement in Social Studies in Ebonyi State, Nigeria. Four research questions and four hypotheses guided the study. The study adopted a correlation survey design. The population of the study consisted of all the 25,298 (twenty five thousand, two hundred and ninety - eight made up of 12,501 male and 12789 female) SSI students in the three Education Zones of Abakaliki, Afikpo and Onueke that sat for the 2018 Junior Secondary School Certificate Examinations. Cluster sampling technique with replacement was employed to select 395 respondents (made up of 194 male and 201 female). Data were collected through a 30 item researchers - developed rating scale structured on a fourpoint rating scale; and Social Studies Achievement Test (SSAT)/30 item objective questions on Social Studies to determine the academic achievement scores of the students. The Instrument was divided into two clusters: cluster A centers on Family Climate with ten 10 items questions, while cluster B centers on Peer Pressure with 10 items questions. The researchers made use of three well trained research assistants to administer the instruments using direct delivery method. The instrument were validated by experts and tested for reliability. They yielded acceptable reliability coefficient values of 0.86; 0.87 respectively on FPRSQ and 0.45 on SSAT using Cronbach Alpha Statistics. Data collected were analyzed using means and Spearman's rho correlation coefficient for research questions while the hypotheses 1, 2 and 3were tested at 0.05 level of significance using regression analyses; hypotheses 4, 5 and 6 were tested using UNIANOVA. The findings of the study include among others; a significant relationship existing between student's family climate and their academic mean achievement in Social Studies;: Based on the findings, recommendations were made by the researchers which include: Parents should make every effort to reduce if not completely do away with broken homes and its causes. Since intact home predisposes good academic performance. On this parents should be enlightened through workshops/seminars on the dangers of unhealthy family climate.
\end{abstract}

Keywords: Family, Family Climate, Peer Pressure, Academic Achievement, Social Studies

\section{Introduction}

\section{Background to the Study}

Family is a basic social group united through bonds of kinship or marriage which is present in all societies. The configuration of the family and the needs that the family fulfills vary from humanity to humanity. In the same view, Ezekiel and Lawal (2014) view the family as a social group characterized by common residence, economic cooperation and reproduction with adults of both sexes, at least two of who maintain a socially approved sexual relationship A family unit is the single parent family, in which children live with an unmarried, divorced, or widowed mother or father. The manner in which any of the family is handled refers to family climate. Family climate can be portrayed according to the interpersonal relationships among the family members, the directions of the personal growth which are emphasized in the system, and the family basic organizational structure. 
Family climate is perceived as consisting of structural and socio-economic circumstance, situations and conditions which are capable of influencing or affecting a child's physical, emotional and educational needs" (Ibeh,2015). Supporting the above definition, Eamon, (2005) sees family climate as the general family environment irrespective of structure that has great control or is competent of influencing a child's sociophysiological and educational growth and development.

Academic achievement on the other hand relates to the performance of students in either or both internal and external examinations in the school. It involves measurable and observable performance that takes place in the presence of a standard of excellence. According to Aremu \& Sokan, (2003), academic achievement has been determined by such variables as: family climate, peer pressure, cognitive learning skills, school environment, society and motivational factors.

According to Majorbanks, (1996) socio-economic status, parental style, family structure (monogamous polygamous), parental involvement and family size are particularly important family factors that influence students' academic achievement in schools.

In the line of the above, Shittu (2004) opines that poor parental care with gross deprivation of social and economic needs of a child usually yield poor academic performance of the child. On the other hand, where a child suffers parental and material deprivation and care due to divorce or death, or if one of the parents absconds, the 'child's schooling may be affected as the mother or father alone may not be buoyant to pay school fees, purchase books and such a child may play truant in the school his performance may be adversely affected. In a home where there is division and parents live in camps of "mother" and "father", the emotional climate of such home is faulty and may discourage the will to achieve in the child. Personal experiences show that instances of this situation exist in society, (i.e.) where husbands and wife are separated or divorced and their children do not live together with them for total parental care and affection. Against the obvious importance of family climate and the conflicting signals of its influence on the child's academic achievement, the study sets out to explore academic achievement relationship with family climate and peer pressure in Ebonyi State.

Related to family climate is the peer pressure. According to Anukam and Anukam (2006), peers are the school mates or colleagues with whom the student interacts on a day to-day basis in his academic pursuit. They are his closest physical neighbor while on campus; they are bound to wield a tremendous influence over his or her life" p.41.

Peer pressure is an influence that a peer group, individual exerts that encourages others to change their attitudes or behaviors to conform to group norms. Peer pressure has been defined as the influence that people of the same social group have on each other (w.w.w.nation/tec.org/tec/.). It is also regarded as an emotional or intellectual force from people of the same social group (such as age, grade or status, political parties, trade union) to act or behave like themselves. The adolescent behaviour is greatly influenced by peer pressure. This influence is a reflection of the adolescent's desire to belong or to be accepted by his or her peers.

Social Studies according to Mbakwem (2009) is a problem-approach through which man studies and learns about problems of survival in his environment. On the whole, the study sets out to investigate how family climate and peer pressure correlate with students' academic achievement in Social Studies in Ebonyi State. Presently, junior secondary school students' interest and academic achievement in social studies is declining. Lemchi (2001) noted that some students are losing interest in the subject which affects students' performance in the subject. Reasons according to Mberengwa (2004), Social Studies teachers teach without instructional materials and facilities; the quality of teachers and class room facilities are grossly inadequate and obsolete. From the foregoing it is evident that there is no one rule of thumb method can be given as a universal solution for all problems of Social Studies instruction. "It should now be apparent that there is no such thing as a method of teaching that is good for all subject matter at all times and in all places.

\section{Statement of the Problem}

The teaching and learning of Social Studies in Nigeria, and Ebonyi State in particular, are faced with many challenges. One of such challenges is the poor academic performance of the students. A prelude survey carried out by the researchers in some schools in Ebonyi State in 2016 and 2017 revealed that they performed poorly in their Junior Secondary School Certificate Examination in Social Studies. For instance, out of 440 students that sat for social studies in 2016 JSSCE examination, from the sampled schools, only 25 got distinction, 105 had credit level while 310 had ordinary pass (EDC:2015). 
In 2017 for example; in one of the sampled schools (St. Kizito Sec. School Izi-Imoha) out 194 students that sat for the subject in 2016, 11 students had distinction, 29 had credits while 154 had ordinary pass. Likewise other schools (EDC, 2017, 2018)

Once more, students appear not to take interest in schooling, in the study of Social Studies and other academic activities (Olaewe, 2004). The reasons for these have become a subject of national discourse involving the effects of family climate and peer pressure among other factors. Though these expressions are personal opinions arising from observations, they however suggest the need to query the characteristics of these students. In other words, it has not been empirically established, comprehensively whether the poor academic achievement in Social Studies in Ebonyi State is as a result of such factors as family climate and peer pressure. People in the State are at a thrashing as to whether the students' poor achievements in Social Studies are as a result of the factors discussed above. The problem therefore is: Are family climate and peer pressure determinants of students' academic achievement in Social Studies?

\section{Scope of the Study}

The study will be enclosed to students' academic achievement and their family climate such as parental marital status, parental style, socio-economic status, and number of siblings and Peer Pressure. Family climate and peer pressure formed the independent variables while Social Studies Achievement Test (SSAT) result used for academic achievement scores is the dependent variable.

\section{Purpose of the Study}

The general purpose of this study is to determine how family climate and peer pressure of secondary school students relate to their academic achievements in Social Studies.

Specifically the study sought to:

1. Determine the relationship between family climate and students' academic achievement in Social Studies.

2. Investigate the relationship between peer pressure and students' academic achievement in Social Studies.

3. Determine the relationship between male and female family climate and their academic achievement in Social Studies.

4. Investigate the relationship between male and female students' peer pressure and their academic achievement in Social Studies.

\section{Significance/ Justification for the Study}

The findings of this study if published will be of immense value to school guidance counselors, Social Studies Educators as well as Curriculum Studies teachers, students, parents, the Ministry of Education, and researchers. Findings from this study would reveal to the Curriculum Studies and Social Studies teachers, what peer pressure and family climate can do in determining students' academic performance. This will equip them with various devices to be used to teach the students. Again the outcome will offer useful framework for teachers who are both the planners and decision makers in classrooms. It will also add to the existing knowledge on family climate, peer pressure and students' academic achievement.

\section{Research Questions}

The following research questions were posed to guide the study:

1. What is the relationship between students' family climate and their mean achievement in Social Studies?

2. What is the relationship between students peer pressure and their mean achievement in Social Studies?

3. What is the relationship between male and female students' family climate and their mean achievements in Social Studies?

4. What is the relationship between male and female students' peer pressure and their mean achievement in Social Studies?

\section{Hypotheses}

The following null hypotheses are formulated to guide the study and will be tested at 0.05 level of Significance.

$\mathrm{HO}_{1}$ There is no statistical significant relationship between students' family climate and their academic achievement score in Social Studies.

$\mathrm{HO}_{2}$ Significant relationship does not exist between students' peer pressure and their academic achievement in Social Studies 
$\mathrm{HO}_{3}$ There is no significant difference in the mean achievement scores of students on family climate based on gender difference.

Ho4 There is no significant difference in the mean achievement scores of students on peer pressure based on gender difference.

\section{Review of Related Literature}

\section{Concept of family climate}

Nnachi, (2009), states that, the family provides the first educational experiences of the child. The type of interaction between the child and the parents counts a lot on the personality of the child. He further added that, if the parents are close enough to the child to educate him or her on the ethics and norms of the society, the child will start in time to receive social education before attending school p.187. Hence, the general climate of the house will teach the child certain norms, values and interpersonal skills which will be of more or less benefits to him when he interacts with the larger environment outside the family, he added. Therefore, parenting style, structure, may influence or determine whether the child would value education or not.On this basis, family climate is perceived as consisting of structural and socio-economic circumstance, situations and conditions which are capable of influencing or affecting a child's physical, emotional and educational need (Goldstein, 2003). Family climate describes the general family environment irrespective of structure that has great influence or is capable of influencing a child's socio-psychological and educational growth and development (Eamon, 2005).

Thus, family climate has the strongest influence in our lives. Our birth order, the personality of our parents, number of our siblings, the way we were treated by our siblings, the socio-economic status of our family, their education, the place lived, parental marital status, the type of house help, all of these shape the child at a time when they were most vulnerable to being shaped (Jeynes, 2002). Supporting this Nnachi, (2009) states that, favourable family environment fosters learning and intellectual development whereas unfavorable family climate or situation can significantly jeopardize learning and cognitive enhancement.

\section{Concept of Peer Pressure}

Peers have been defined as children or adolescents who are about the same age or maturity level (Hartup, 1983), However, Dworetzky (1981) defined peer relationship as interactions among children of approximately the same age. For normal social development of the students, good peer relations may be necessary. Peer pressure on the other hand is defined as the influence of people of your own age in encouraging or urging you to do something or to keep off from doing something else, no matter if you personally want to do it or not (Ryan, 2000). In the same vein, Encarta (2009) defines peer pressure as a social pressure on somebody to adopt a type of behaviour, values, or attitude in order to be accepted as part of a group. Peer pressure can either be positive (good) or negative (bad). Negative peer pressure is when an adolescent is coerced to do what is wrong. Peer pressure in the words of the researchers is a term that comprises a set of group dynamics where by a group in which one feels comfortable may override personal habits, individual moral inhibitions or idiosyncratic desires to impose a group norm or attitude.

\section{Concept of Academic Achievement}

Achievement is defined as measurable behaviour in a standardized series of tests (Simpson and Weiner. 2018). Achievement test is usually constructed and standardized to measure proficiency in school subjects. According to Bruce and Neville (2017) educational achievement is measured by standardized achievement test developed for school subjects. What this means is that academic achievement is measured in relation to what is attained at the end of a course, since it is the accomplishment of medium or long term objective of education. Simpson and Weiner (2018) contended that achievement test intends to measure systematic education and training in school occupation towards a conventionally accepted pattern of skills or knowledge.Okoro and Ibebuike (2013) defined academic achievement as the learning outcomes of the child. The researchers concludes by allying with the definition of Asiebgu (2015) which states that academic achievement are frequently expressed and measured in form of good scores and prizes as a result of hard work and exceptional performance in classroom test, assignment and examination.

\section{Theoretical Framework: Achievement Goal Theory}

Bandura (1977) developed this theory in his efforts to integrate cognitive and affective components of goal directed behaviour. This theory posits the existence of two-achievement goal constructs namely performance and mastery goals. 
Performance goals are tied to the belief that ability affects outcome, whereas mastery goals are tied to the belief that effort affects outcome. Mastery goals are associated with the intrinsic value of learning and the maintenance of achievement- directed behaviour over time.This theory is very relevant to this study. A student's ability in school is capable of affecting his academic achievement in class. This has implications for teaching and learning in schools. Teachers are to make students realize that their mental abilities are capable of influencing their academic achievement school. This, to a great extent, will help make students balance their study behaviours so that their achievement in school is not affected negatively. In this case, the teachers can maintain achievementdirected behaviours among the students over time and this could result in high academic achievement.

\section{Empirical framework}

Eyo (2011) conducted a study on the relationship between peer pressure and students' academic achievement in Calabar central. The purpose of the study was to ascertain whether any relationship existed between family pressure and student's achievement in secondary schools. The study was a correlation study. The subjects for this study were 267 high school students The findings from the study indicated significant relationship between peer pressure and academic achievement with internals having higher achievements than externals. The findings also indicate that males particularly showed internal score to academic competence and social maturity than females. This study is related to the present study because it centered on the influence of peer pressure on academic achievement of secondary school students.

\section{Methodology}

\section{Design}

The researchers adopted a correlational survey design. The study was carried out in Ebonyi State. The target population for this study comprised all the twenty five thousand, two hundred and ninety eight $(25,298)$ SSI students in three education zones of Ebonyi State. Data collected from, Planning, Research and Statistics(PRS) SEB, Abakaliki (August,2018) reveal that there are 25,298 SSI students made up of 12,509 and 12789 male and female SSI students respectively in Ebonyi State. The sample for this study comprised 395 respondents made up of 194 and 201 male and female SS I students respectively. The subjects were selected using Cluster Sampling technique with replacement. The researchers used Yaro Yamane formulae to determine the sample size. Furthermore, the researcher used proportionate sampling technique to select 30 schools (representing $7.4 \%$ ) out of the 221 public schools in the state. The ratio for the schools thus: Onueke=9schools, Afikpo=11 schools, and Abakaliki $=10$ schools. The percentage ratio for the respondents in each zone is thus: Onueke $=116$ respondents representing 29.35\%; Afikpo zone=141 respondents representing 35.70\%; while Abakaliki zone $=138$ representing $34.94 \%$. This gave 395 respondents from the 30 secondary schools and this constitutes $13.57 \%$ approximately $14 \%$ of the entire population.

Researchers-developed rating scale titled "Family Climate, Peer Pressure rating scale (FCPPRS) and Social Studies Achievement Test (SSAT) were the instruments for data collection. The instrument is made up of Part "A" and "B" Part A is on the personal data of the respondents. Part B is a 4-point scale and has 2 clusters. Cluster 1 covers family climate with 10 items; Cluster 2 has 10 items on peer pressure while Social Studies Achievement Test (SSAT) is a 30 item objective questions centered on Social Studies. The results obtained from the SSAT were used to determine the academic achievement scores of the students.

The face validity of the two instruments were determined by the researchers by presenting copies of FCPPRSQ and SSAT together with the purpose of the study, research questions and hypotheses to five experts, three taken from Social Studies and two from Measurement and Evaluation. For the reliability test, the researchers administered the instrument to 40 SSII secondary school students in some selected public secondary schools in Enugu State .This was done within interval of two weeks. The scores obtained from the respondents were collated to determine the correlation co-efficient. The Correlation Co-efficient of the sets of scores for the items in each section was obtained using Cronbach Co-efficient Alpha. The reliability indices for the two sections include 0.86 and 0.87, while that of SSAT is 0.45.The researchers administered the instrument using Direct Delivery Technique (DDT) with the help of three well trained research assistants, one each from the three Education Zones in the State. Each research assistant covered his or her own education zone. Data collected were analyzed using SPSS (Statistical Package for Social Sciences) version 18. Answers to research questions were sought using means and Spearman's rho correlation coefficient; while the hypotheses were tested with the help of Regression Analysis at 0.05 level of significance. 
The decision rule for this analysis says thus: if the P-value is less than 0.05 which is the level of confidence reject the hypothesis. Whereas if the P-value is greater than 0.05, Accept the hypothesis. For research questions the values are thus:to $0.03=$ weak, 0.04 to $0.06=$ Borderline, 0.07 to $0.09=$ very strong.

Thus it could be positive (+v) or negative (-v)

\section{Presentation of Results}

Research Question 1: What is the relationship between students' family climate and their mean academic achievement in Social Studies?

Table1: Spearman's rho Relationship between Students' Family Climate and their Academic Achievement in Social Studies

Correlations

\begin{tabular}{|l|l|l|c|c|}
\hline & & & $\begin{array}{l}\text { MEAN FAMILY } \\
\text { CLIMATE }\end{array}$ & SCORES \\
\hline Spearman's rho & MEAN FAMILY & Correlation Coefficient & 1.000 & $-.196^{* *}$ \\
& CLIMATE & Sig. (2-tailed) & .000 \\
& & $\mathrm{~N}$ & 394 & 390 \\
\hline & SCORES & Correlation Coefficient & $-.196^{* *}$ & .000 \\
& & Sig. (2-tailed) & 390 & 391 \\
\hline
\end{tabular}

**. Correlation is significant at the 0.01 level (2-tailed).

The result in table 1 shows the relationship between students' family climate and their academic mean achievement in Social Studies. It was indicated from the table that the correlation coefficient accounts for -0.196 with a p-value of 0.000 indicating a negative influence existing between students' family climate and their academic achievement in Social Studies. The result therefore accounts for a significant relationship existing between students' family climate and their academic mean achievement in Social Studies.

Research Question 2: What is the relationship between students' peer pressure and their mean academic achievement in Social Studies?

Table2: Spearman's rho Relationship between Peer Pressure and students' mean Academic Achievement in Social Studies

Correlations

\begin{tabular}{|c|c|c|c|c|}
\hline & & & SCORES & $\begin{array}{l}\text { MEAN PEER } \\
\text { PRESSURE }\end{array}$ \\
\hline Spearman's rho & SCORES & $\begin{array}{l}\text { Correlation Coefficient } \\
\text { Sig. }(2 \text { - tailed }) \\
\text { N }\end{array}$ & $\begin{array}{r}1.000 \\
391\end{array}$ & $\begin{array}{r}-.057 \\
.260 \\
391\end{array}$ \\
\hline & MEAN PEER PRESSURE & $\begin{array}{l}\text { Correlation Coefficient } \\
\text { Sig. }(2-\text { tailed }) \\
\text { N }\end{array}$ & $\begin{array}{r}-.057 \\
.260 \\
391 \\
\end{array}$ & $\begin{array}{r}1.000 \\
395\end{array}$ \\
\hline
\end{tabular}

The result in table 2 shows the relationship between peer pressure and student's mean academic achievement in Social Studies. The result has shown no relationship existing between peer pressure and student's academic achievement in Social Studies as the correlation coefficient accounts for -0.057 and a p-value of 0.260.

Research Question 3: What is the relationship between male and female students' family climate and their academic achievement in Social Studies?

Table3: Spearman's Correlation Coefficient Result for Male and female Students' Family Climate and their Academic Achievement in Social Studies

Correlations 


\begin{tabular}{|c|c|c|c|c|}
\hline Male & & & $\begin{array}{l}\text { MEAN FAMILY } \\
\text { CLIMATE }\end{array}$ & SCORES \\
\hline Spearman's rho & $\begin{array}{l}\text { MEAN FAMILY } \\
\text { CLIMATE }\end{array}$ & $\begin{array}{l}\text { Correlation Coefficient } \\
\text { Sig. }(2-\text { tailed }) \\
\text { N }\end{array}$ & $\begin{array}{r}1.000 \\
193\end{array}$ & $\begin{array}{r}. \\
.291 * * \\
.005 \\
189\end{array}$ \\
\hline & SCORES & $\begin{array}{l}\text { Correlation Coefficient } \\
\text { Sig. }(2-\text { tailed }) \\
\text { N }\end{array}$ & $\begin{array}{l}-.202 * * \\
.005 \\
189\end{array}$ & $\begin{array}{r}1.000 \\
190\end{array}$ \\
\hline
\end{tabular}

**. Correlation is significant at the 0.01 level (2-tailed).

\section{Correlations}

\begin{tabular}{|c|c|c|c|c|}
\hline Female & & & $\begin{array}{l}\text { MEAN FAMILY } \\
\text { CLIMATE }\end{array}$ & SCORES \\
\hline Spearman's rho & $\begin{array}{l}\text { MEAN FAMILY } \\
\text { CLIMATE }\end{array}$ & $\begin{array}{l}\text { Correlation Coefficient } \\
\text { Sig. }(2 \text { - tailed }) \\
\text { N }\end{array}$ & $\begin{array}{r}1.000 \\
201\end{array}$ & \begin{tabular}{r}
\multicolumn{1}{c}{-} \\
$.195 * *$ \\
.006 \\
201 \\
\end{tabular} \\
\hline & SCORES & $\begin{array}{l}\text { Correlation Coefficient } \\
\text { Sig. }(2 \text { - tailed }) \\
\text { N }\end{array}$ & $\begin{array}{l}.195 * * \\
.006 \\
201 \\
\end{array}$ & $\begin{array}{r}1.000 \\
201\end{array}$ \\
\hline
\end{tabular}

**. Correlation is significant at the 0.01 level (2-tailed).

The result in table 3 shows the spearman's correlation coefficient output reporting the level of co-relationship that exists between male students' family climate and their academic achievement in Social Studies. The result has accounted for a negative relationship existing between male students' family climate and their academic achievement in Social Studies as the result accounts for a correlation coefficient $\left(r_{s}\right)$ of -0.202 and a p-value of 0.005. The relationship that exists between male students' family climate and their academic achievement in Social Studies is a weak and a negative relationship.The result in table 3 also shows the spearman's correlation coefficient output reporting the level of co-relationship that exists between female students' family climate and their academic achievement in Social Studies. The result has also accounted a negative and weak relationship existing between female students' family climate and their academic achievement in Social Studies as the result accounts for a correlation coefficient $\left(\mathrm{r}_{\mathrm{s}}\right)$ of -0.195 and a p-value of 0.006 .

Research Question4: What is the relationship between male and female students' peer pressure and their academic achievement in Social Studies?

Table 4: Spearman's Correlation Coefficient Output for male and female students' peer pressure and their academic achievement in Social Studies

Correlations

\begin{tabular}{|c|c|c|c|c|}
\hline & & & SCORES & $\begin{array}{l}\text { MEAN PEER } \\
\text { PRESSURE }\end{array}$ \\
\hline Spearman's rho & SCORES & $\begin{array}{l}\text { Correlation Coefficient } \\
\text { Sig. }(2 \text { - tailed }) \\
\text { N }\end{array}$ & $\begin{array}{r}1.000 \\
190\end{array}$ & $\begin{array}{l}-.203 * * \\
.005 \\
190\end{array}$ \\
\hline & $\begin{array}{ll}\text { MEAN } & \text { PEER } \\
\text { PRESSURE } & \end{array}$ & $\begin{array}{l}\text { Correlation Coefficient } \\
\text { Sig. }(2-\text { tailed }) \\
\text { N }\end{array}$ & $\begin{array}{l}-.203^{* *} \\
.005 \\
190\end{array}$ & $\begin{array}{r}1.000 \\
19 \dot{4}\end{array}$ \\
\hline
\end{tabular}

**. Correlation is significant at the 0.01 level (2-tailed).

Correlations

\begin{tabular}{|c|c|c|c|c|}
\hline & & & SCORES & $\begin{array}{l}\text { MEAN PEER } \\
\text { PRESSURE }\end{array}$ \\
\hline Spearman's rho & SCORES & $\begin{array}{l}\text { Correlation Coefficient } \\
\text { Sig. }(2 \text { - tailed }) \\
\text { N }\end{array}$ & $\begin{array}{r}1.000 \\
201\end{array}$ & $\begin{array}{l}.066 \\
.351 \\
201\end{array}$ \\
\hline & MEAN PEER PRESSURE & $\begin{array}{l}\text { Correlation Coefficient } \\
\text { Sig. }(2 \text { - tailed }) \\
\text { N }\end{array}$ & $\begin{array}{l}.066 \\
.351 \\
201\end{array}$ & $\begin{array}{r}1.000 \\
201\end{array}$ \\
\hline
\end{tabular}


The result in table 4 shows the spearman's correlation coefficient output reporting the level of co-relationship that exists between male students' peer pressure and their academic achievement in Social Studies. The result has also shown that there is a negative and weak co-relationship existing between male students' peer pressure and their academic achievement in social studies as the result accounts for a correlation coefficient $\left(r_{s}\right)$ of -0.203 and a pvalue of 0.005 .

The result in table 4 also reports Spearman's correlation coefficient output showing the level of co-relationship that exists between female students' peer pressure and their academic achievement in Social Studies. The result has accounted for no relationship existing between female students' peer pressure and their academic achievement in social studies as the result accounts for a correlation coefficient $\left(r_{s}\right)$ of 0.351 and a $p$-value of 0.066 .

\section{Testing of Hypotheses}

Ho: : There is no statistical significant relationship between students' family climate and their academic achievement score in social studies $(\mathrm{p}<0.05)$.

Table 5:Summary of Regression Analysis on the students' family climate and their academic achievement score in Social Studies $\mathbf{p}<0.05$.

\begin{tabular}{|l|l|l|l|}
\hline \multicolumn{4}{|c|}{ Model Summary } \\
\hline R & R Square & Adjusted R Square & P-value \\
\hline 0.157 & 0.025 & 0.022 & 0.001 \\
\hline
\end{tabular}

The table above shows a summary of the Regression Analysis output produced using SPSS 18. The result reports that there is a significant relationship existing between students' family climate and their academic achievement score in Social Studies $(\mathrm{p}<0.05)$ as the $\mathrm{p}$-value which accounts for 0.001 is less than 0.05 being the level of confidence, with $\mathrm{R}$ square $=0.022$ and $\mathrm{R}=0.157$. This means that the researcher Reject $\mathrm{H}_{0}$ and conclude that there is a significant relationship existing between students' family climate and their academic achievement score in Social Studies $(\mathrm{p}<0.05)$. This is to show that students' family climate does have a significant influence on their academic achievement in social studies.

$\mathbf{H o}_{2}$ : Significant relationship does not exist between students' peer pressure and their academic achievement in social studies $(\mathrm{p}<0.05)$.

Table 6:Summary of Regression Analysis on the students' peer pressure and their academic achievement in Social Studies p $<0.05$.

\begin{tabular}{|l|l|l|l|}
\hline \multicolumn{4}{|l|}{ Model Summary } \\
\hline R & R Square & Adjusted R Square & P-value \\
\hline 0.063 & 0.004 & 0.001 & 0.106 \\
\hline
\end{tabular}

Table 6 above shows a summary of the Regression Analysis output produced using SPSS 18. The result revealed that there is no statistical significant relationship existing between students' peer pressure and their academic achievement in Social Studies as the p-value which accounts 0.106 is greater than 0.05 being the confidence level, with $\mathrm{R}$ square $=0.004$ and $\mathrm{R}=0.063$. This means that the researcher Accept $\mathrm{H}_{0}$ and conclude that there is no significant relationship existing between students' peer pressure and their academic achievement in Social Studies $(p<0.05)$. This is to show that students' peer pressure does not have significant influence on their academic achievement in Social Studies.

Table 7: Analysis of covariance results for the difference in the mean achievement scores of students on family climate based on gender difference.

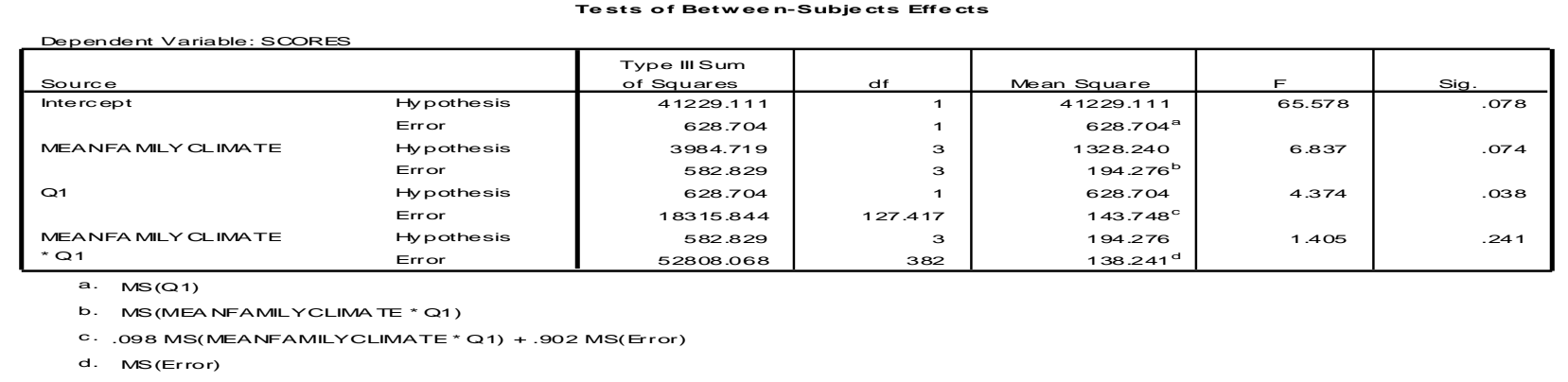


The result shows that the calculated F-value is 1.405 for the effects of treatment on achievement scores of students' on family climate based on gender difference, while the P-value accounted for a 0.241. Our decision shall be made based on P-value, stating that if P-value is less than 0.05 , then the researcher will reject the null hypothesis. For the result, P-value which accounts for 0.241 is greater than 0.05 , the researcher therefore accepts the null hypothesis which states that, there is no significant difference in the mean achievement scores of students on family climate based on gender difference.

Table 8: Analysis of covariance result for the difference in the mean achievement scores of students on Peer pressure based on gender difference

Tests of Between-Subje cts Effects

\begin{tabular}{|c|c|c|c|c|c|c|}
\hline Source & & $\begin{array}{l}\text { Type III Sum } \\
\text { of Squares }\end{array}$ & $\mathrm{df}$ & Mean Square & $\mathrm{F}$ & Sig. \\
\hline \multirow[t]{2}{*}{ Intercept } & Hy pothesis & 98445.871 & 1 & 98445.871 & \multirow[t]{2}{*}{361.111} & \multirow[t]{2}{*}{.00} \\
\hline & Error & 755.512 & 2.771 & $272.619^{\mathrm{a}}$ & & \\
\hline \multirow[t]{2}{*}{ MEANPEERPRESSURE } & Hypothesis & 703.703 & 3 & 234.568 & \multirow[t]{2}{*}{.537} & \multirow[t]{2}{*}{.69} \\
\hline & Error & 1088.193 & 2.492 & $436.601^{\mathrm{b}}$ & & \\
\hline \multirow[t]{2}{*}{ Q1 } & Hypothesis & 839.486 & 1 & 839.486 & \multirow[t]{2}{*}{1.639} & \multirow[t]{2}{*}{.321} \\
\hline & Error & 1107.873 & 2.162 & $512.345^{\mathrm{C}}$ & & \\
\hline MEANPEERPRESSURE & Hy pothesis & 1139.389 & 2 & 569.694 & 3.924 & .021 \\
\hline${ }^{*} \mathrm{Q} 1$ & Error & 55746.341 & 384 & $145.173^{d}$ & & \\
\hline
\end{tabular}

a. $.195 \mathrm{MS}(\mathrm{Q} 1)-.018 \mathrm{MS}\left(\mathrm{MEANPEERPRESSURE}{ }^{*} \mathrm{Q} 1\right)+.824 \mathrm{MS}($ Error $)$

b. .686 MS(MEANPERPRESSURE* Q1) +.314 MS(Eror)

c. .865 MS(MEANPERPRESSURE* Q1) +.135 MS(Error)

d. MS(Error)

The result above shows that the calculated F-value is 3.924 for the effects of treatment on achievement scores of students' on Peer Pressure based on gender difference while the P-value accounted for a 0.021. Our decision shall be made based on P-value, stating that if P-value is less than 0.05, then the researcher will reject the null hypothesis. For the result, P-value which accounts for 3.924 is greater than 0.05 , the researcher therefore accepts the null hypothesis which states that, there is no significant difference in the mean achievement scores of students on Peer Pressure based on gender difference.

\section{Discussions}

\section{Family climate and Academic Achievement}

Result of the study in table 1 showed the relationship between students' family climate and their academic achievement in Social Studies. The result revealed that family climate generally affects students' academic achievement in Social Studies in Ebonyi State. This result shows that family climate significantly affects students' academic achievement. The result of this study confirmed the findings of Anyakohia and Nnajieto (2014) who found that family structure and type of parenthood significantly influenced academic performance of students.

In null hypothesis one; there is no statistical significant relationship between students' family climate and their academic achievement score in social studies $(\mathrm{P}<0.05)$. Observation from the analysis of regression at 0.05 level of significance revealed that a $\mathrm{P}-$ value of 0.001 which is less than the researcher's level of confidence. Therefore the researcher rejected hypothesis $\left(\mathrm{HO}_{1}\right)$ based on the decision rule that when P-value is less than the confidence interval $(\mathrm{P}<0.05)$, the hypothesis is rejected. Hence the researchers conclude that there is a significant relationship between students' family climate and their academic achievement score in Social Studies.

\section{Peer Pressure and Academic Achievement}

Table 2 shows the relationship between peer pressure and student's academic achievement scores in social studies. A Correlation Coefficient account of -0.057 with a $\mathrm{P}-$ value of 0.260 was obtained; indicating that no relationship exists. This finding runs conversely with the words of Reuben (2013), who stated that the negative influence of peer pressure on the adolescent was dangerous especially in the areas of talking you into taking drugs, shoplifting, absenting from classes. In null hypothesis two; Significant relationship does not exist between students' peer pressure and their academic achievement in social studies $(\mathrm{P}<0.05)$. 
Observation from the analysis of regression at 0.05 level of significance shows that a $\mathrm{P}$-value which is greater than the level of confidence, with $\mathrm{R}$ Square $=0.004$ and $\mathrm{R}=0.063$ was obtained. The researcher therefore accept $\left(\mathrm{HO}_{2}\right)$ the hypothesis and conclude that there is no statistical significant relationship existing between students' peer pressure and their academic achievement in social studies $(\mathrm{P}<0.05)$.

\section{Summary of Findings}

From the analyses above, the following findings were made:

1. There is a significant relationship existing between students' family climate and their academic achievement in Social Studies.

2. There is no relationship existing between peer pressure and student's academic achievement in social studies.

3. There is a negative and weak relationship existing between male students' family climate and their academic achievement in Social Studies.

\section{Recommendations}

Based on the findings of this study, the researchers made the following recommendations;

1. Parents should at all-time listen carefully and be close to their wards, not only to verbal communications but to nonverbal communications and to the emotions that may lie beneath what is said.

1. Parents should make every effort to reduce if not completely do away with broken homes and its causes. Since intact home predisposes good academic performance. On this parents should be enlightened through workshops/seminars on the dangers of unhealthy family climate.

2. Actively encouraging positive peer friendship and associations that will affirm the young person's good qualities and subtly model attitudes and abilities he or she may lack. Parents should also monitor the friends their children keep so that they do not join bad companies, and possibly drop out of school. This is because peers exert influence on the student's academic achievement.

\section{References}

Anukam, I.L and Anukam, H.O. (2006), The Hidden curriculum and School Administration. Owerri: Skillmark media Ltd.

Anderson, J.R. (1990). Acquisition of Cognitive Skills, New York: John Wiley and sons.

Anyakohia, C.I. and Nnajieto, C.C,(2014), Parental type and its influence on the academic performance of secondary school students in Owerri education zone. In Journal of Research Studies in Education.1:1.4145.

Anyamene, A.N.(2000).The relationship between secondary school students' cognitive learning skills and their academicachievements. Unpublished Ph.D Thesis, NnamdiAzikiwe University Awka.

Asiebgu, C.E.(2015). Study habits and academic performance of secondary school students in Awka South Local Government Area of Anambra State In National Journal of Educational LeadershipVol.2.

Aremu, A.O. and Oluwole, DA (2001). Gender and birth order as predictors of normal pupil's anxiety pattern in examination. Ibadan Journal of Educational Studies, 1, (1), $1-7$.

Aremu, A.O.., and Sokan, B.O. (2003). A multi-causal evaluation of academic performance of Nigerian learner: issues and implications for national development. In Ayodele- Bamisaiye, O; Nwazuoke, I .A. \&Okediran, A. (eds), Education This Millennium (pp 365-375). Ibadan: Macmillan Nig. Ltd.

Akinbote, O.A. (1999) Sex differences in the cognitive and effective outcomes in social studies of primary school pupils. African Journal of Educational Research 5(1).34-38.

Azuka- Obieke,U.(2013).Single-Parenting, psychological well-being and academic performance of adolescents in Lagos, Nigeria. Journal of Emerging Trends in Educational Research and Policy Studies (6).

Bandura, A. (1977). Social learning theory. Englewood Cliffs, NJ: Prentice Hall.

Bandura, A. (1991). Social cognitive theory of self-regulation.Organizational Behavior and Human Decision Processes, 50, 248-287.

Bruce, H. C. \& Neville, P (2017).Evaluation in education.Oxford:Pengamon Press.

Bornstein, P (2002). The effects of a self- instructional package on overactive preschool boys.Journal of Applied Behaviour Analysis. 9, 179 - 188. 
Dheimann, D., (2018) Social Learning theory or Social Cognitive theory.Retrieved July $26^{\text {th }} 2018$ from http://.comminit.com/global/content/social-learning-theory-or-social-cognitive-theory.

Duru, V.N. (2011).Curriculum Studies, concepts, development and implementation.Owerri: Avan Global publications.

Eamom, M.K. (2005). Social-demographic, school, neighbourhood, and parenting influences on academic achievement of Latino young adolescents.Journal of Youth and Adolescent, 34 (2),163-175.

Effiong,V.N,;Edinyang,S.D.; Awhen,O.F.(2014).Teaching Social Studies with Concept Mapping Instructional Strategy.Nigerian Journal of Social Studies and Civic Education. 6 (1)245.

Eyo, S.O. (2011). Perceived relationship between peer pressure and students academic achievement in schools.Multidisciplinary Journal of Research and Development.2(1).

Ezewu, J.I. (2010). Relationship between peer pressure and students self-concept.International Journal of Educational Research 5(1).

Ezekiel, A.D.andLawal, R.(2014),Social factors as determinants of Academic Achievement of students: An overview. Journal of Research Studies in Education.1(1).

Ibeh, A.I. (2015). Family climate, peer pressure and cognitive leaning skills as correlates of students academic achievement in social studies in Ebonyi State of Nigeria. An unpublished Ph.D Dissertation, Imo State University, Owerri, Imo State.

Jackson, B. (2015). Cognitive Approach to Study Strategies. Rockville: Md Aspen.

Jeynes, W. H. (2002). Examining the effects of parental absence on the academic achievement of adolescents: the challenge of controlling for family income.Journal of Family and Economic Issues 23 (2),31 - 39.

Marton, F.(1993). On qualitative differences in the study and practice of education. Journal of Educational Psychology 46, 12-25.

Machr, M. L., andArcher,J. (2007). Motivation and school achievement In L.G. Katz (Ed.), Current topics in early childhood education. Hillside, N.J., :Albex publishing corporation.

Misra, R. (2012). "College students' academic stress and its relation to their anxiety time management and leisure satisfaction. American Journal of Health Studies 41-51.

Mbakwem, J.N.(2009).Millennium development goals, Social Studies and Nation- Biulding. Owerri: Zionbless Publishers Co.

Nnachi, R.O. (2009), Advanced Psychology of learning and scientific Enquiries.Owerri: Totan Publishers.

Nuhu, J.I.; Suleiman,L.; Manir,H. (2014).The role of education in reducing family violence. Journal of Research Studies in Education 1 (1).

Olaewa, D.O. (2004). Teachers quality variables and students factors as determinants of academic achievement in mathematics among senior secondary schools students. An unpublished Ph.D, Thesis, Department of Guidance and Counseling, University of Ibadan. 